\title{
T LYMPHOCYTE EFFECTOR MECHANISMS IN THE RETINA IN POSTERIOR UVEITIS
}

\author{
K. BARTON and S. LIGHTMAN \\ London
}

\begin{abstract}
SUMMARY
Loss of vision in posterior uveitis is often the consequence of chronic retinal oedema and immune-mediated damage to the retinal parenchyma. Research in other putative autoimmune diseases such as rheumatoid arthritis, and in animal models of autoimmune disease, has uncovered a number of mechanisms which may contribute to the development of inflammatory disease within the eye. With recent developments in specific anti-cytokine therapy an understanding of these mechanisms, most of which are cytokine-mediated, is essential in order to plan more effective therapeutic strategies. In this paper we review recent research investigating the functional characteristics of the $\mathbf{T}$ cells which are recruited into the retina in experimental autoimmune uveoretinitis, including activation status, antigen-specific proliferation in vitro and cytokine mRNA production in the inflamed retina.
\end{abstract}

Involvement of the posterior segment of the eye occurs in $14-43 \%$ of uveitides in Western societies, representing an annual incidence of 3.9-7.3/100 000.' In the majority of these patients inflammatory episodes can be controlled by systemic or periocular steroids and disease remission can be maintained either without drugs or by prescribing a low daily maintenance dose. A proportion of posterior uveitis patients require $20 \mathrm{mg}$ or more of prednisolone per day for long periods in order to prevent relapse and this obviously has major side-effects in the long term. Other patients, such as those with Behçet's disease, inexorably lose vision despite relatively good long-term control of their inflammatory disease. ${ }^{2}$ Drugs which specifically control inflammatory activity within the eye and prevent the development of the sequelae of uveitis without a significant risk of systemic toxicity are clearly lacking.

The major reasons for loss of vision are macular oedema due to breakdown of the blood-retina barrier (Fig. 1), direct inflammatory damage to retinal elements, retinal vessel closure with consequent ischaemic changes,

From: Department of Clinical Science, Institute of Ophthalmology, London, UK.

Correspondence to: Mr K. Barton, MRCP, FRCS, Moorfields Eye Hospital, City Road, London ECIV 2PD, UK.

Eye (1994) 8, 60-65 C 1994 Royal College of Ophthalmologists and glaucomatous optic neuropathy. In order to develop new therapies for uveitis, an understanding of the immunological mechanisms which lead to these sequelae is essential. The main difficulty in achieving this is the relative inaccessibility of the tissue involved.

Immunohistochemical studies of the retina and choroid of eyes enucleated for the complications of various types of posterior uveitis such as Behçet's disease, ${ }^{3}$ sarcoidosis and sympathetic ophthalmia ${ }^{4}$ have demonstrated that the predominant infiltrating cell is the $\mathrm{CD}^{+} \mathrm{T}$ cell. Although this does not prove that the aetiology is autoimmune, the absence of a demonstrable cause, in combination with the recognised associations with other putative autoimmune conditions and the clinical response to immunosuppressive drugs, provide strong circumstantial evidence for an autoimmune aetiology.

In other organ-specific putative T-cell-mediated auto-

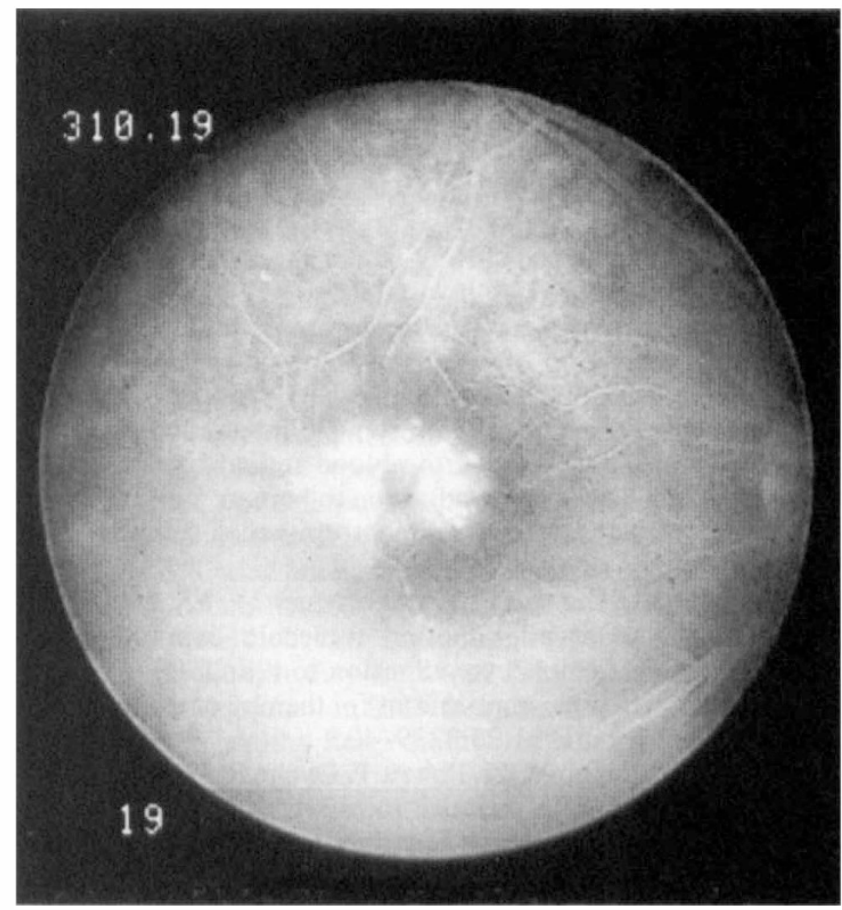

Fig. 1. Fundus fluorescein angiogram of a patient with macular oedema due to inflammatory disease. 
immune diseases such as rheumatoid arthritis ${ }^{5.6}$ and Graves' thyroiditis, ${ }^{7.8}$ the functional characteristics of lymphocytes extracted from inflamed tissue have been studied extensively in vitro. The information obtained from such work has contributed to many of the current concepts of how autoimmune diseases develop.

If it were feasible to obtain viable lymphocyte preparations from the retinas of patients with uveitis, we would hope to discover how $\mathrm{T}$ cells can cross the blood-retina barrier to induce an inflammatory response within the normally protected environment of the retina. A step in this direction is the characterisation of lymphocytes from the retinas of animals with experimental autoimmune uveoretinitis (EAU).

Functional and phenotypic data have been reported from lymphocytes obtained from the retinas of animals with EAU. ${ }^{9}$ Expression of activation markers, antigenspecific lymphocyte proliferation and cytokine mRNA production within the retina were examined. ${ }^{10}$ The results are reviewed in the context of our current knowledge of the pathogenesis of human uveitis.

\section{EXPERIMENTAL AUTOIMMUNE UVEORETINITIS}

Animal models of posterior uveitis (EAU) can be induced by peripheral injection of a purified retinal antigen (e.g. $S$ antigen, $\mathrm{S}-\mathrm{Ag}$ ) emulsified in adjuvant, which leads to the development of retinochoroiditis after approximately 2 weeks. ${ }^{11}$ Although uveal antigens have been shown to cause anterior uveitis, they are much less effective in producing uveoretinitis. ${ }^{12,13}$

The injection of antigen into the foot pad results in the generation of activated ocular antigen-specific $\mathrm{CD}^{+} \mathrm{T}$ cells in the popliteal and inguinal lymph nodes. They enter the circulation and some reach the retinal vasculature to cause EAU. When removed from one animal, cultured in

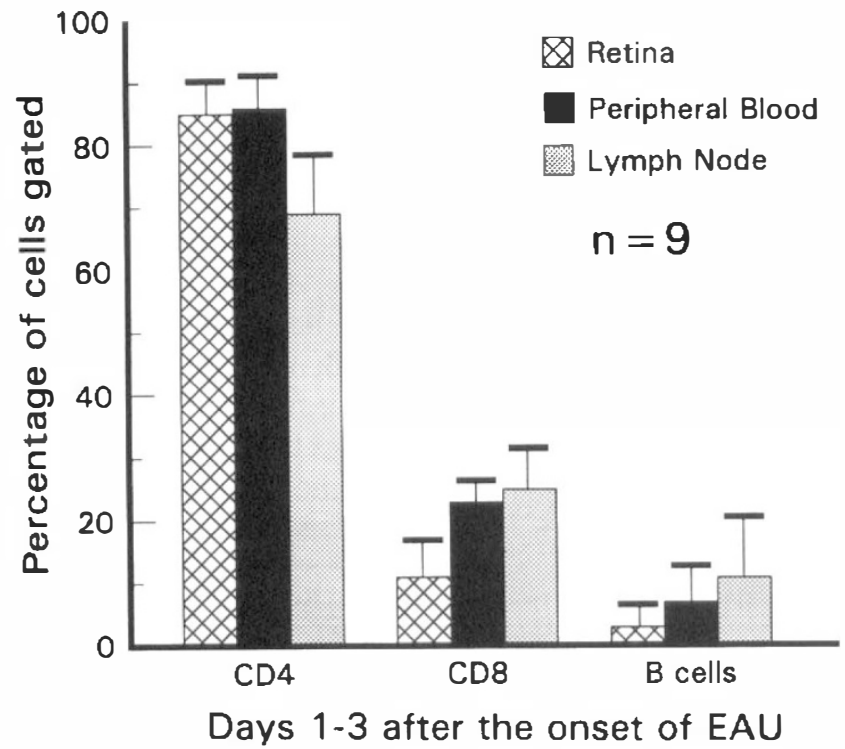

Fig. 2. Bar chart demonstrating the relative proportions of $C D 4^{+}$T lymphocytes, $C D 8^{+}$T lymphocytes and B lymphocytes in the retinas of Lewis rats with experimental autoimmune uveoretinitis in early disease. vitro in the presence of antigen and then injected into a syngeneic animal, these lymphocytes can induce EAU in the recipient (adoptive transfer), demonstrating that the $\mathrm{CD} 4^{+} \mathrm{T}$ cell is responsible for induction of the disease. ${ }^{14}$

\section{Induction of EAU}

EAU was induced in the Lewis rat model by an injection into the foot pad of $50 \mu \mathrm{g}$ purified bovine retinal S-Ag emulsified in complete Freund's adjuvant containing $2.5 \mathrm{mg} / \mathrm{ml}$ Mycobacterium tuberculosis. At the same time $5 \times 10^{9}$ killed Bordetella pertussis organisms were injected intraperitoneally.

With this regime a severe fulminant uveoretinitis, with concomitant anterior uveitis, hypopyon and vitritis, develops between days 11 and 13 after immunisation. The inflammation peaks in severity from days 13 to 15 and gradually resolves by days 18 to 21 (7-10 days after onset).

\section{PHENOTYPE AND ACTIVATION STATE OF $\mathrm{CD4}^{+} \mathrm{T}$ LYMPHOCYTES WITHIN THE RETINA}

$\mathrm{T}$ cell subset phenotypes have previously been studied in retinal infiltrates in EAU using immunohistochemistry. ${ }^{15.16}$ These reports were largely qualitative and the expression of lymphocyte activation markers by individual subsets was not examined. As there is some evidence that lymphocytes within the eye in EAU are activated, probably reflecting the method of their recruitment from the circulation, we examined $T$ cell subsets in the retina by immunocytochemistry and flow cytometry so that levels of co-expression of the interleukin-2 receptor (IL-2R) and CD45R (an isoform of the leucocyte-common antigen) by the $\mathrm{CD}^{+}$subset could be examined. Lymph node and peripheral blood lymphocytes were compared with those from retina. Significance was assessed using the Wilcoxon rank sum test.

\section{Lymphocyte Subsets in the Retina}

Eighty-one per cent of the total lymphocytes infiltrating the retina in early disease were $\mathrm{CD}^{+}$(Fig. 2). When the $\mathrm{CD}^{+}{ }^{+} \mathrm{T}$ cells are examined in isolation, IL-2R expression

Table I. Expression of IL-2R and CD45R by $\mathrm{CD}^{+} \mathrm{T}$ cells

\begin{tabular}{|c|c|c|c|}
\hline $\begin{array}{l}\text { Days after } \\
\text { disease onset }\end{array}$ & $\begin{array}{l}\text { Retina } \\
(n)\end{array}$ & $\begin{array}{l}\text { Peripheral } \\
\text { blood }\end{array}$ & $\begin{array}{l}\text { Lymph } \\
\text { node }\end{array}$ \\
\hline \multicolumn{4}{|l|}{ IL-2R } \\
\hline $1-3$ & $33.7 \pm \frac{ \pm}{(7)} 6.2$ & $4.3 \pm 0.6$ & $7.4 \pm 1.8$ \\
\hline $5-8$ & $21.7 \pm \frac{ \pm}{(5)} 7.8$ & $9.9 \pm 7.0$ & $19.6 \pm 5.2$ \\
\hline \multicolumn{4}{|l|}{ CD45R } \\
\hline $1-3$ & $4.7 \frac{ \pm}{(7)} 1.2$ & $68.4 \pm 2.2$ & $60.4 \pm 6.6$ \\
\hline $5-8$ & $45.6 \pm \frac{15)}{(5)} 17.8$ & $68.4 \pm 8.0$ & $71.0 \pm 3.3$ \\
\hline
\end{tabular}

Mean percentages of lymphocytes \pm SEM staining CD4 and IL-2R or $\mathrm{CD} 45 \mathrm{R}$ double positive respectively on two-colour immunofluorescence. $n$, number of experiments, five pooled retinas per experiment. 
in the retina was significantly higher than in either lymph node or peripheral blood preparations $(p<0.01)$ (Table I) confirming that at least $34 \%$ of these cells are activated. This marker is expressed only transiently and such a high level implies that a large proportion of the $\mathrm{CD}^{+} \mathrm{T}$ cells in the retina have been activated.

There was similarly a sharp contrast between the percentage of $\mathrm{CD}^{+} \mathrm{T}$ lymphocytes expressing CD45R in inflamed retina and those in peripheral blood $(p<0.001)$ and lymph nodes $(p<0.01)$. CD45R labels two-thirds of peripheral blood $\mathrm{CD} 4^{+} \mathrm{T}$ cells in the normal rat ${ }^{17}$ and identifies a subpopulation which produces IL-2 and interferon- $\gamma(\mathrm{IFN}-\gamma){ }^{18}$ The $\mathrm{CD} 45 \mathrm{R}^{-}$subset differs functionally, produces mainly IL- $4,-5$ and -6 , and has been implicated in the suppression of autoimmune diseases induced by $\mathrm{CD} 45 \mathrm{R}^{+} \mathrm{CD} 4^{+} \mathrm{T}$ cells.

However, the picture is confused somewhat by the CD45 $\mathrm{R}^{+}$subset which ceases to express this marker after activation, and although it is possible that the $95 \%$ of $\mathrm{CD}^{+} \mathrm{T}$ cells in the retina which are $\mathrm{CD} 45 \mathrm{R}^{-}$might have originated from the constitutively $\mathrm{CD}^{-} 4 \mathrm{R}^{-}$population, it is more likely that they are CD45R ${ }^{-}$because they have been activated. This result does illustrate that lymphocytes within the retina are phenotypically different from those in the peripheral blood, explaining the lack of specificity of many peripheral blood markers in uveitis.

Similar levels of CD45R expression have been observed in studies in human rheumatoid arthritis where the $\mathrm{CD} 45 \mathrm{RO}^{+} \mathrm{T}$ lymphocyte (present on activated $\mathrm{CD}^{+} \mathrm{T}$ lymphocytes in the human and analogous in a number of respects to $C D 45 \mathrm{R}^{-}$in the rat) is the predominant lymphocyte in the inflamed synovial joint. Evidence from the rheumatoid joint suggests that lymphocytes of this phenotype accumulate in the retina due to selective migration or retention rather than local proliferation. ${ }^{19}$

\section{Late Disease}

During disease resolution, the relative proportion of $\mathrm{CD} 8^{+}$ $\mathrm{T}$ lymphocytes increased in the retina $(p<0.05)$, as previously reported. ${ }^{15,16}$ It has been suggested that this might be due to selective retention within the retina, ${ }^{15}$ the $\mathrm{CD} 88^{+} \mathrm{T}$ cells having an immunosuppressive role. However, recent studies of CD8-depleted rats with EAU do not support this $^{20}$ and analysis of other cell phenotypes demonstrates that there is a concurrent increase in B cell levels $(p<0.05)$ and $\mathrm{CD} 45 \mathrm{R}^{+} \mathrm{CD}^{+} \mathrm{T}$ cells as well as $\mathrm{CD} 8^{+} \mathrm{T}$ cells.

It has been shown that the $\mathrm{CD} 45 \mathrm{R}^{+} \mathrm{CD} 4^{+}$population includes some cells which may subserve memory function. ${ }^{21}$ Although it is possible that those $\mathrm{CD} 45 \mathrm{R}^{+}$cells seen in the retina in late disease are memory cells, as suggested by reports of an increased frequency of IFN- $\gamma$ mRANproducing lymphocytes by in situ hybridisation in late disease, ${ }^{22}$ it is also possible that the destruction of the blood-retina barrier which occurs in EAU results in the passive entry of naive $\mathrm{CD} 45 \mathrm{R}^{+} \mathrm{CD} 4^{+} \mathrm{T}$ lymphocytes from the circulation. The latter possibility is supported by the relatively mixed lymphocyte population which we have observed in the retina in late disease.

\section{ANTIGEN SPECIFICITY OF LYMPHOCYTES WITHIN THE RETINA}

Evidence from adoptive transfer experiments suggests that uveitis develops when only a small proportion of injected ocular antigen-specific $\mathrm{CD}^{+} \mathrm{T}$ lymphocytes accumulate in the eye. ${ }^{23.24}$ Congenitally athymic Lewis rats fail to develop disease on adoptive transfer of uveitogenic $\mathrm{T}$ cell lines alone, but the capacity to induce EAU is restored when these animals are immunologically reconstituted with spleen and thymus cells from syngeneic euthymic donors. It is probable that only a small number of uveitogenic lymphocytes are required to initiate an inflammatory response within the eye and the majority are recruited from elsewhere in the immune system during an amplification phase. ${ }^{25}$

This being the case we would expect only a small proportion of lymphocytes within the retina to be specific for the inducing antigen, S-Ag. In order to investigate this, the proliferative response of lymphocytes extracted from retinas to S-Ag in tissue culture was compared with that to purified protein derivative of $M$. tuberculosis (PPD), a relevant non-ocular antigen present in the adjuvant used to induce EAU. The stimulation indices (SI) obtained from retinal lymphocyte preparations in response to stimulation with S-Ag and PPD were modest but similar in magnitude and significant (Table II). The response to $\mathrm{S}-\mathrm{Ag}$ could be blocked by anti-MHC class II monoclonal antibodies $(\mathrm{mAb})$, indicating that it was $\mathrm{CD}^{+} \mathrm{T}$-cell-mediated.

The proliferative response observed in lymph node preparations was consistently greater than that in retinal lymphocyte preparations and similarly blocked by antiMHC class II mAb, suggesting a low frequency of cells specific for the antigens tested within the retina. However, previous studies of the interaction of $\mathrm{T}$ cell lines with retinal pigment epithelium (RPE) ${ }^{26}$ and Müller cell ${ }^{27}$ cultures have suggested that although retinal cells can stimulate $\mathrm{T}$ cell lines in vitro by presenting antigen to them under very carefully controlled circumstances, it seems likely that Müller cells normally have an overall inhibitory influence on lymphocyte proliferation in vivo, possibly explaining the weakness of the proliferative response to antigen which we observed. ${ }^{28.29}$

Studies in other autoimmune conditions have suggested that with progression of the disease, diversification of the range of antigen-specificities may occur in inflamed tissue. ${ }^{30}$ This would be in keeping with our observations, but further investigation of lymphocyte function in isolation, separated from the influence of other resident retinal cells, is required and this is logistically more difficult.

Table II. Antigen-specific proliferation

\begin{tabular}{lcc}
\hline Antigen & Retina & Lymph node \\
\hline S-Ag & $2.8 \pm 0.44$ & $5.1 \pm 1.13$ \\
PPD & $2.8 \pm 0.39$ & $3.8 \pm 0.64$ \\
S-Ag + anti-MHC class II mAb & $\begin{array}{c}(4) \\
\pm 0.17\end{array}$ & $1.8 \pm 0.50$ \\
& $(6)$ & \\
\hline
\end{tabular}

Mean stimulation index $\pm \operatorname{SEM}(n)$ for lymphocyte proliferation assays. 


\section{CYTOKINE PRODUCTION WITHIN THE INFLAMED RETINA}

The $\mathrm{CD}^{+} \mathrm{T}$ lymphocyte is believed to influence the development of the inflammatory response in the retina by a combination of mechanisms which include activation of the retinal capillary endothelium, MHC class II expression on resident retinal cells and direct retinal parenchymal cell damage. The common factor which influences all of these is the cytokine milieu created in the retina by the infiltrating lymphocytes. Although $\mathrm{CD}^{+} \mathrm{T}$ lymphocytes have been demonstrated to have a cytotoxic effect in some circumstances, ${ }^{31.32}$ the majority of their effects appear to be mediated via the production of cytokines. It is possible, therefore, that selective interference with cytokine production or with cytokine receptors could have a profound effect on the inflammatory response.

In 1986 Mosman et al. reported that murine $\mathrm{T}$ cell clones in long-term culture displayed two distinct patterns of cytokine production, ${ }^{33}$ and so the terms T helper type 1 (Th1) and T helper type 2 (Th2) were coined. Thl cells produce IL-2, IFN- $\gamma$ and lymphotoxin (LT) and are believed to be important in delayed-type hypersensitivity reactions. Th2 cells, on the other hand, produce interleukins-4, -5, -6 and -10, (IL-4, IL-5, IL-6 and IL-10) and their main role is in helping $\mathrm{B}$ cells. Although there is some evidence that this division may not be so clearcut in man, ${ }^{34}$ it provides a useful working model.

EAU is largely a delayed-type hypersensitivity response and uveitogenic $\mathrm{T}$ cell lines have been reported to demonstrate a Thl pattern of cytokine secretion (R. R. Caspi, unpublished). However, $\mathrm{CD}^{+} \mathrm{T}$ lymphocytes in retinal infiltrates in EAU have shown a mixed pattern of cytokine mRNA production by in situ hybridisation. ${ }^{35}$ As immunisation with S-Ag provokes a humoral as well as a cellular response and activated $T h 2 \mathrm{~s}$ involved in generation of this humoral response can cross the blood-retina barrier, it would be surprising if retinal infiltrates exhibited only a purely $T h l$ pattern of cytokine secretion.

Cytokine mRNA production within the retina in EAU has also been examined using reverse transcription-polymerase chain reaction (RT-PCR) followed by Southern blotting and hybridisation (Fig. 3). Total RNA was extracted from whole tissue and mRNA present in the sample selectively reverse transcribed to complementary DNA (cDNA). In the polymerase chain reaction, minute quantities of cDNA specific for the lymphokine in question were selectively amplified during repetitive cycles of DNA denaturation and synthesis. $\beta$-actin cDNA sequences were also amplified by PCR to ensure that each cDNA sample had been reverse transcribed to a comparable degree.

The PCR products were analysed initially by agarose gel electrophoresis and then transferred onto nylon membranes (Southern blotting). The Southern blots were probed with a radiolabelled DNA fragment the base pair sequence of which was complementary to part of the

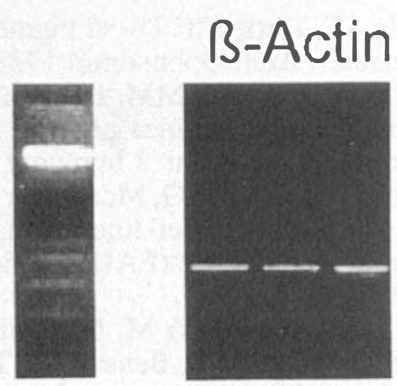

a.

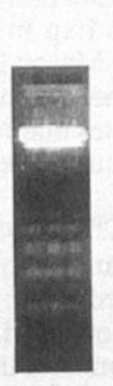

a.

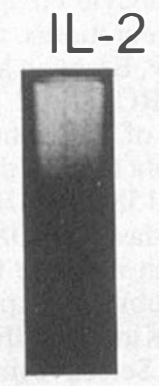

b.

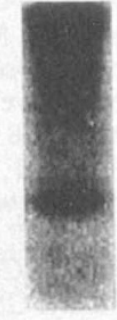

C.

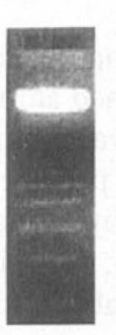

a.

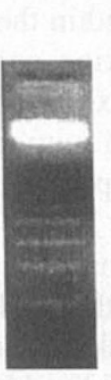

a.

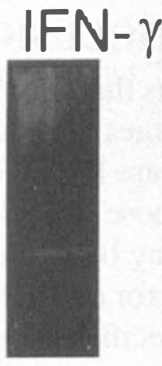

b.

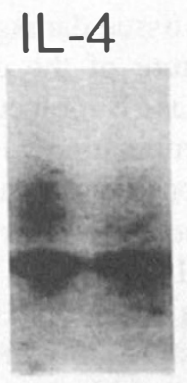

C.

Fig. 3. IFN- $\gamma, I L-2, I L-4$ and $\beta$-actin (control for reverse transcription) PCR products as seen after agarose gel electrophoresis (b) and Southern blotting and hybridisation (c). A 123 base pair DNA molecular weight ladder $(a)$ gives an indication of the size of the PCR product. 
amplified lymphokine sequence (hybridisation) and autoradiographed. This is an extremely sensitive method of detecting PCR products.

In preliminary experiments IFN- $\gamma$, IL- 2 and IL- 4 mRNA were detected relatively early in EAU, 24-48 hours from the onset of disease. The signal for IL-4 was consistently weaker in that it was detectable only by hybridisation and autoradiography, in contrast to the IL-2 and IFN- $\gamma$ lymphokine PCR products which were detectable by agarose gel electrophoresis alone (Fig. 3). These findings would suggest that there are both Thl-like and Th2-like patterns of cytokine mRNA produced in the retina in early EAU and that there is, if anything, a predominance of $T h l$-like cells. Interestingly, IL-4 mRNA seems to persist with similar intensity into late disease, while IL- 2 and IFN- $\gamma$ mRNA products are more difficult to detect in late disease. It may be that this indicates a relative shift towards a Th2 pattern at this stage; however, as IL-4 may be produced by cells other than $T$ lymphocytes, analysis of mRNA production by another Th2 cytokine such as IL-10 will be necessary to confirm that the presence of IL-4 mRNA does indicate Th2 activity. Transcription of lymphokine sequences to mRNA does not necessarily imply translation into protein; however, previous immunohistochemical studies which have found IFN- $\gamma$ protein in relative abundance in inflamed retina in EAU $^{35}$ and the high expression of IL-2R on lymphocytes in the retina described above, would tend to support the conclusion that these mRNA species are translated into protein in the retina during EAU.

\section{CONCLUSION}

Evidence to date suggests that $\mathrm{CD} 4^{+}$lymphocytes found in the retina in the early stages of established animal models of autoimmune disease are highly activated and different phenotypically from those found in peripheral blood. Although the disease may be initiated by a small number of lymphocytes specific for one antigen, diversification of the range of antigen specificities probably occurs as the response mounts and other lymphocytes are recruited into the retina.

Many of the mechanisms involved in this recruitment and in the subsequent tissue damage within the retina are dependent on the nature of the cytokine environment. IFN- $\gamma$ causes MHC class II molecule expression in aberrant sites. IFN- $\gamma$ in combination with LT, tumour necrosis factor or IL-1 is responsible for the appearance of adhesion molecules such as E-selectin and ICAM-1 on vascular endothelium. ${ }^{36}$ Interleukins themselves, or acting indirectly by inducing production of other inflammatory products such as prostaglandins and leukotrienes, may be responsible for the loss of integrity of the blood-retina barrier.

It is likely that specific anti-lymphokine therapy to tame the unwanted effects of IFN- $\gamma$ and other cytokines will have a profound effect on the management of intraocular inflammation and the prevention of its sequelae.

Key words: Cytokines, Experimental autoimmune uveoretinitis, Pathogenesis, T lymphocytes, Uveitis.

\section{REFERENCES}

1. Baarsma GS. The epidemiology and genetics of endogenous uveitis: a review. Curr Eye Res 1992;11 Suppl:1-9.

2. BenEzra D, Cohen E. Treatment and visual prognosis in Behçet's disease. Br J Ophthalmol 1986;70:589-92.

3. Charteris DG, Barton K, McCartney ACE, Lightman SL. $\mathrm{CD} 4^{+}$T lymphocyte involvement in ocular Behçet's disease. Autoimmunity 1992;12:201-6.

4. Lightman S, Chan C-C. Immune mechanisms in choroidoretinal inflammation in man. Eye 1990;4:345-53.

5. Van Boxel JA, Paget SA. Predominantly T-cell infiltrate in rheumatoid synovial membranes. N Engl J Med 1975;293: 517-20.

6. Feldmann M, Brennan FM, Chantry D, Haworth C, Turner $\mathrm{M}$, Abney $\mathrm{E}$ et al. Cytokine production in the rheumatoid joint: implications for treatment. Ann Rheum Dis 1990;49: 480-6.

7. Londei M, Bottazzo GF, Feldmann M. Human T-cell clones from autoimmune thyroid glands: specific recognition of autologous thyroid cells. Science 1985;228:85-9.

8. Mackenzie WA, Schwarz AE, Friedman EW, Davies TF. Intrathyroidal $\mathrm{T}$ cell clones from patients with autoimmune thyroid disease. J Clin Endocrinol Metab 1987;64:818-24.

9. Barton K, Calder VL, Lightman S. Isolation of lymphocytes from the retina in experimental autoimmune uveoretinitis: phenotypic and functional characterisation. Immunology 1993;78:393-8.

10. Barton K, McLauchlan MT, Calder VL, Lightman S. Interleukin-2, interferon- $\gamma$, and interleukin- 4 production by lymphocytes in the retina in EAU [abstract]. Invest Ophthalmol Vis Sci 1993;34:2172.

11. Wacker WB, Donoso LA, Kalsow CM, Yankeelov JA, Organisciak DT. Experimental allergic uveitis: isolation, characterisation and localization of a soluble uveitopathogenic antigen from bovine retina. J Immunol 1977;119: 1949-58.

12. Woods AC, Little MF. Uveal pigment; hypersensitivity and therapeusis. Arch Ophthalmol 1933;9:200-26.

13. Wacker WB, Lipton MM. Experimental allergic uveitis. I. Production in the guinea pig and rabbit by immunisation with retina in adjuvant. J Immunol 1968;101:151-6.

14. Caspi RR, Roberge FG, McAllister C, El-Saied M, Kuwabara T, Gery I et al. T cell lines mediating experimental autoimmune uveoretinitis (EAU) in the rat. J Immunol 1986; 136:928-33.

15. Chan C-C, Mochizuki M, Nussenblatt RB, Palestine AG, McAllister C, Gery I, Benezra D. T-lymphocyte subsets in experimental autoimmune uveitis. Clin Immunol Immunopathol 1985;35:103-10.

16. Brown EC, Kasp E, Dumonde DC. Morphometric analysis of $\mathrm{T}$ lymphocyte compartmentation in experimental autoimmune uveoretinitis. Clin Exp Immunol 1989;77:422-7.

17. Spickett GP, Brandon MR, Mason DW, Williams AF, Woollett GR. MRC OX-22, a monoclonal antibody that labels a new subset of T lymphocytes and reacts with the high molecular weight form of the leukocyte-common antigen. J Exp Med 1983;158:795-810.

18. Powrie F, Mason D. OX-22 $2^{\text {high }} \mathrm{CD} 4^{+} \mathrm{T}$ cells induce wasting disease with multiple organ pathology: prevention by the OX-22 ${ }^{\text {low }}$ subset. J Exp Med 1990;172:1701-8.

19. Pitzalis C, Kingsley GH, Covelli M, Meliconi R, Markey A. Panayi GS. Selective migration of the human helper-inducer memory $\mathrm{T}$ cell subset: confirmation by in vivo cellular kinetic studies. Eur J Immunol 1991;21:369-76.

20. Calder VL, Zhao ZS, Wang YF, Barton K, Lightman S. Effects of CD8-depletion on S-antigen induced experimental autoimmune uveoretinitis. Immunology 1993;79: 255-62.

21. Powrie F, Fowell D, McKnight AJ, Mason D. Lineage relationships and functions of $\mathrm{CD}^{+} \mathrm{T}$-cell subsets in the rat. Res Immunol 1991;142:54-8. 
22. Charteris DG, Lightman SL. Interferon gamma (IFN- $\gamma$ ) production in vivo in experimental autoimmune uveoretinitis. Immunology 1992;75:463-7.

23. Palestine AG, McAllister C, Carter C, Keenan AM, Vistica $\mathrm{B}$, Gery I et al. Lymphocyte migration in the adoptive transfer of EAU. Invest Ophthalmol Vis Sci 1986;27:611-5.

24. Lightman S, Caspi RR, Nussenblatt RB, Palestine AG. Antigen-directed retention of an autoimmune $T$ cell line. Cell Immunol 1987;110:28-34.

25. Caspi RR, Chan CC, Fujino Y, Najafian F, Grover S, Hansen CT, Wilder RL. Recruitment of naive T cells plays a pivotal role in the pathogenesis of experimental autoimmune uveoretinitis [abstract]. Invest Ophthalmol Vis Sci 1993;34:902.

26. Percopo CM, Hooks JJ, Shinohara T, Caspi RR, Detrick B. Cytokine-mediated activation of a neuronal retinal resident cell provokes antigen presentation. J Immunol 1990;145: 4101-7.

27. Roberge FG, Caspi RR, Nussenblatt RB. Glial retinal Müller cells produce IL-1 activity and have a dual effect on autoimmune T helper lymphocytes. J Immunol 1988;140: 2193-6.

28. Caspi RR, Roberge FG, Nussenblatt RB. Organ-resident, non-lymphoid cells suppress proliferation of autoimmune $T$ helper lymphocytes. Science 1987;237:1029-32.

29. Chan C-C, Roberge FG, Ming M, Zhang W, Nussenblatt RB. Injury of Müller cells increases the incidence of experimental autoimmune uveoretinitis. Clin Immunol Immunopathol 1991;59:201-7.
30. Lehmann PV, Sercarz EE, Forsthuber T, Dayan CM, Gammon G. Determinant spreading and the dynamics of the autoimmune T-cell repertoire. Immunol Today 1993;14: 203-8.

31. Rosenberg AS, Mizuochi T, Singer A. Analysis of T cell subset in rejection of $\mathrm{Kb}$ mutant skin allografts differing at class I MHC. Nature 1986;322:829-31.

32. Erb P, Grogg D, Troxler M, Kennedy M, Fluri M. CD4 ${ }^{+} \mathrm{T}$ cell-mediated killing of MHC class II positive antigenpresenting cells. I. Characterisation of target cell recognition by in vivo or in vitro activated CD $4^{+}$killer T cells. J Immunol 1990;144:790-5.

33. Mosmann TR, Cherwinski H, Bond M, Giedlin MA, Coffman RL. Two types of murine helper T cell clone. J Immunol 1986; 136:2348-57.

34. Paliard X, Malefit R, Blanchard D, Chretien I, Abrams J, Vries J, Spits H. Simultaneous production of IL-2, IL-4 and interferon- $\gamma$ by activated human $\mathrm{CD}^{+}$and $\mathrm{CD} 8^{+} \mathrm{T}$ cell clones. J Immunol 1988;141:849-55.

35. Charteris DG, Lightman SL. In vivo lymphokine production in experimental autoimmune uveoretinitis. Immunology 1992;78:387-92.

36. Liversidge J, Sewell HF, Forrester JV. Interactions between lymphocytes and cells of the blood-retina barrier: mechanisms of $\mathrm{T}$ lymphocyte adhesion to human retinal capillary endothelial cells and retinal pigment epithelial cells in vitro. Immunology 1990;71:390-6. 